Article

\title{
Open Innovation and Social Big Data for Sustainability: Evidence from the Tourism Industry
}

\author{
Pasquale Del Vecchio*(D), Gioconda Mele, Valentina Ndou and Giustina Secundo \\ Department of Engineering for Innovation, University of Salento, 73100 Lecce, Italy; \\ gioconda.mele@unisalento.it (G.M.); valentina.ndou@unisalento.it (V.N.); giusy.secundo@unisalento.it (G.S.) \\ * Correspondence: pasquale.delvecchio@unisalento.it; Tel.: +39-083-229-7919
}

Received: 3 August 2018; Accepted: 6 September 2018; Published: 8 September 2018

\begin{abstract}
This paper aims to contribute to the debate on Open Innovation in the age of Big Data by shedding new light on the role that social networks can play as enabling platforms for tourists' involvement and sources for the creation and management of valuable knowledge assets. The huge amount of data generated on social media by tourists related to their travel experiences can be a valid source of open innovation. To achieve this aim, this paper presents evidence of a digital tourism experience, through a longitudinal case study of a destination in Apulia, a Southern European region. The findings of the study demonstrate how social Big Data could open up innovation processes that could be of support in defining sustainable tourism experiences in a destination.
\end{abstract}

Keywords: sustainability; tourism; open innovation; tourism destination; Social Big Data

\section{Introduction}

In the knowledge economy, Big Data arises as the most representative paradigm and an issue of priority interest for researchers and practitioners [1-3]. Despite the ubiquity of the term, its implications and meaning for the activities of managers and entrepreneurs are under-researched [4-6] and mainly concern practices of open innovation. The large diffusion of web 2.0 and digital technologies have radically changed firms' open innovation strategies by creating the processes of users' empowerment, as well as larger and more highly participated innovation processes $[7,8]$. This is because as open, low cost and ubiquitous tools, digital technologies allow firms to tap into the knowledge and experiences of a larger number of actors, allowing them to actively participate in the open innovation process $[9,10]$.

Big Data encompasses all industries but becomes especially relevant for knowledge intensive ones, such as tourism, where its emergence is assumed as the basis of the smart configuration of the industry [11] and the identification of knowledge as lever for innovation and competitiveness of destinations [11]. Here a Tourism destination is defined as set of products and services that offer tourists an integrated experience [12,13].

Big Data in tourism, in particular, has the potential to add value in accordance with the dimensions suggested by Brown et al. [14] in terms of transparency and immediate feedback, quick experimentation, customers segmentation, decision-making and products or services innovation. The opportunities related to the use of Big Data for informing a range of decisions related to processes, customers, competition and innovation arise for guiding organizational strategies for the future, and to grasp insights for improving daily operations, growth, efficiency or competitive differentiation [15]. All the emerging applications of Big Data in Tourism have been recently analyzed in a paper by Li et al. 2018 [16] providing a structured literature review according to three main dimensions of data sources (users, devices and operations).

All this makes the challenge of creating value from Big Data for Smart Tourism one of growing relevance in an open perspective, by highlighting large opportunities resulting from the management 
of knowledge flows generated and available on social networks and web 2.0 platforms. The processes and methods used by companies and organization to extract and manage this kind of knowledge, characterized by different formats and contents, are defined as Social Big Data [17] and represent a new source of relevant knowledge for improving the effectiveness of the decision-making process [18], as well as in terms of sustainability.

Sustainability is a crucial issue for the business agenda today, as it is considered a business driver that has the potential to improve performance as well as to offer a source of competitive advantage [19,20]; the same applies for the tourism sector. According to Buhalis [13] the competitiveness of tourism destinations is based on the destination's capacity to continuously attract tourists by offering a high quality and unique experiences, ensuring benefits for stakeholders, local community and the territory and in doing so enabling sustainable development.

The principles of sustainability refer to "the environmental, economic, and socio-cultural aspects of tourism development and a suitable balance must be established between these three dimensions to guarantee its long-term sustainability" [21] (pp. 11,12).

The importance of sustainability in tourism was also recently underlined by the World Economic Forum [22] in its report regarding the performance of world tourism destinations, where it was established that a destination that does not develop in a sustainable way cannot be considered to be a competitive destination [23]. This suggests the need for adoption of investigative frameworks characterized by cross-disciplinary theoretical perspectives and resulting from the integration of consolidated and emerging theories and approaches in the fields of business management, IT management, tourism management, sustainable regional development.

Framed in the above premises, this paper aims to understand how the huge amount of data generated on social media by tourists, and related to their travel experiences, can support open innovation in defining sustainable tourism experiences in a destination.

Therefore, the evidence of a longitudinal analysis of a single case study is presented. The case considered refers to a digital local tourism experience related to Apulia, a Southern European region and destination of growing popularity.

Based on the integration of business analytics and interviews with key actors, the case aims to demonstrate the role of social Big Data to sustain the open innovation process of the destination's local offerings in terms of ideation, R\&D (Research and Development) and commercialization as the main phases of an open innovation strategy defined by Mount and Garzia Martinez [8].

The paper is structured as follows: In the literature background, research streams related to Big Data, Open Innovation and Smart Tourism with the aim to highlight the relevance and the interlink of these three constructs for the open innovation process in the digital age; the methodology section presents the research approach adopted as well as the context of study; the findings describe the evidence resulting from social Big Data analytics about the digital local experience and its impact on the open innovation process. Finally, implications are presented for the advancement of the research agenda in the fields of Open Innovation, Smart Tourism and sustainability, as well as for policy makers and managers involved in the innovative management of tourism destinations.

\section{Literature Background}

\subsection{Big Data and Open Innovation}

Big Data is a major trend for academics and practitioners and represents a promising frontier for the advancement of knowledge in the fields of both information technology and management $[1,6,23,24]$. As ubiquitous term, Big Data refers to all datasets requiring a large amount of time to be analyzed and the embrace of different tools [1,3]. The debate on Big Data has focused attention on some specific features related to: The nature of data (i.e., structured or unstructured, video, images, text, codes), and analysis methods and tools $[6,24,25]$. In regards to the sources, two main types of Big Data can be identified: Data from and about the physical world (generated by 
sensors, scientific observations etc.) and data from and about human society (generated by social networks, internet, marketing, etc.) [5]. Some variables have been assumed as lens for shaping the complexity characterizing the technological (Volume, Velocity, Variety) and managerial dimensions (Veracity, Variability and Value) of Big Data $[3,26,27]$.

Big Data interests all productive sectors and there is not a single business or industry that can be excluded from its potential usage as a strategic factor. Their adoption can produce radical changes into the daily choices of individuals and organizations, and its impact on society can be disruptive [5]. Furthermore, the management of Big Data requires advanced and technology-based analytical approaches, sophisticated statistical algorithms such as machine learning, sentiment analysis, business analytics, clustering and social network analysis, to get insight and support decision making processes [28].

Different research studies have highlighted the opportunities and benefits that the collection, elaboration and analysis of Big Data could bring to firms in terms of innovation, efficiency, productivity, quality and customer satisfaction, thus representing a key competitive advantage [29].

Considering that in the Open Innovation paradigm the external knowledge is used for the innovation process and to expand the markets, Big Data could be identified as an open innovation source, encompassing the use of purposive inflows and outflows of knowledge, useful to accelerate innovation within organizations [30]. Therefore, it could be claimed that a natural relationship exists between Big Data and open innovation. Both deals with external sources of knowledge that could be highly relevant for achieving business excellence and innovation [2,31].

In particular, social Big Data, as a sum of data generated and shared on social media platforms, are increasingly being used as tools for external stakeholders' engagement [7] and to acquire new external knowledge useful to develop new products, services, distribution and production methods etc. In an open innovation perspective, social Big Data enables firms to co-create value with customers and stakeholders by acquiring additional knowledge and skills for innovation processes [32-34] mainly from customers and users, as highlighted by Von Hippel [35].

Furthermore, knowledge generated in social media provide a basis of deep and different source since the contributors have different expertise, skills and experiences that can be appropriately applied to the innovation process. Because Big Data is the result of varied and diversified information and data, open innovation is argued to be a suitable approach to assure the transformation of these data into inputs for the innovation process of companies [36].

Yet, despite its relevance and increased attention there is limited research in exploring the role of Big Data, in particular social Big Data, as a source of open innovation that facilitates the innovation process at its different stages-Ideation, $R \& D$ and Commercialization [8]. More specifically, for each stage more details are provided.

Ideation stage - Social Big Data constitute a relevant source of innovation for gaining knowledge regarding new trends, customer preferences and product performances coming from different external stakeholders that if efficiently elaborated on provide relevant insights and ideas for the first stage of the innovation process and new opportunities for internal creativity. The large amount of knowledge generated in social media could provide market insights and contribute in the identification of emerging trends [28] and new customers' needs [37].

$R \mathcal{E} D$ stage - data generated in social media can be used as relevant mechanisms for sustaining development of new products and services. Different studies have demonstrated the role of Big Data in products' innovation [38] and firms' predictive activity [39]. Specific technologies and analytical methods can allow the exploitation of social Big Data to predict market trends, to generate new insights and to identify new trends which are relevant for feeding the internal process of innovation and development. This could then result in improved performance, better decision making, customization and personalization of offerings, product/service innovation and new business models that are all elements of value that could be created through Big Data [14,15,26,40-43]. 
Commercialization stage — as a channel for sharing customers' experiences and information about the products and services [44], social media constitute a relevant promotional and marketing channel for product commercialization. Social media constitutes a strong word-of-mouth channel that can drive commercialization and marketing of products through peer-recommendations. Also, analysis of data related to brand reach, preferences, market extension etc. provide relevant insights for product commercialization [15,41].

\subsection{Smart Tourism Destinations: Social Big Data for Open Innovation}

A tourism destination is a complex collection of diverse components of economic, social and environmental factors, all of which are deeply inter-connected [12]. Its competitiveness is affected by knowledge creation and management as supported by the diffusion of technological platforms and knowledge-intensive services $[45,46]$.

The interaction of a destination with the community of stakeholders, residents and tourists, based on dynamic platforms, knowledge intensive communication flows and enhanced decision support systems is the factor charactering the emergence of a Smart Tourism Destination, as an archetype of an intelligent configuration characterized by high degree of innovation, open, shared and integrated services enhancing the quality of life [11,47-51].

The Smartness of a Tourism Destination is a recent new frontier of studies in the tourism industry characterized by interdisciplinary perspectives in terms of models, tools and strategies and several policy implications [13,52-57]. The integration of technologies, systems, services, and capabilities in a structural view impacting on cross-sectorial actors and institutions is a pre-condition for the development of a Smart Tourism Destination [58,59].

The emergence of the Big Data paradigm is naturally related to Smart Tourism. It has been argued that as enhanced information and tourists' online content are on social media, they provide the basis for Big data analytics to develop Smart City services and provide a better understanding of tourist behaviors [60].

The study of a Smart Tourism Destination could be realized through a multidimensional framework based on three smart layers: information (about the collection of data), exchange (interconnectivity), processing (data analysis) [61]. Other studies have identified four main principal areas in smart tourism ecosystem, including actors, tools, resources and institutions, that could be useful for managers to foster innovation and value creation in the long run [62].

The final objectives of a Smart Tourism Destination are represented by efficiency, sustainability and experience enrichment. This is made possible by embracing advanced tools to collect, aggregate and analyze data generated by physical infrastructures and social connections into on-site experiences [37,63,64]. This could satisfy the demand of tourists more and more in an all-inclusive local experience including a set of different goods and services [13]. It is in this venue that the definition offered by Neuhofer et al. [65] on "technology enhanced tourism experiences" shows its relevance and it can be assumed as the synthesis of a smart tourism configuration. This is coherent also with the sustainability principles for tourism destinations that have been identified into "the ability of a destination to create and integrate value added products that help to maintain the position and market share and/or improve it in the long run" [66] (p. 23).

Social media and digital technologies can be useful in creating Smart Tourism Destinations since they enable dynamic connections, and networking [67]. They can also allow us to create, monitor and manage online communities [68] and can operate as a powerful source of Big Data [69], supporting the acquisition of relevant knowledge about customers' experiences, feelings, interests, opinions, behaviors, and preferences etc. [2,55,70-72]. It is in this vein, that Big Data and their management are identified as a strategic driver for Smart Tourism $[61,63,73]$.

The main contributions provided in the literature are briefly reported in Table 1. 
Table 1. Big Data and Smart Tourism: Main Contributions.

\begin{tabular}{|c|c|c|}
\hline Author/s & Year & Main Evidence \\
\hline Sigala et al. [52] & 2012 & $\begin{array}{l}\text { The role of Web } 2.0 \text { technologies to empower Internet users for producing, } \\
\text { consuming and diffusing information and knowledge. }\end{array}$ \\
\hline Fuchs et al. [70] & 2014 & $\begin{array}{l}\text { The application of Big data analytics for knowledge creation and application as a } \\
\text { precondition for organizational learning at tourism destinations. }\end{array}$ \\
\hline Xiang et al. [55] & 2015 & $\begin{array}{l}\text { Demonstrate the utility of big data analytics to comprehend important hospitality } \\
\text { issues, from a large quantity of consumer reviews extracted from Expedia.com }\end{array}$ \\
\hline Gretzel et al. [63] & 2015 & $\begin{array}{l}\text { Discussion of the issues and elements related to smart tourism, its current trends, } \\
\text { and the technological and business foundations. }\end{array}$ \\
\hline Buhalis, Foerste [68] & 2015 & $\begin{array}{l}\text { SoCoMo marketing based on contextual information collected by a wide range of } \\
\text { sensors for developing smart and for influencing the tourist experience. }\end{array}$ \\
\hline Marine-Roig, Clavè [71] & 2015 & $\begin{array}{l}\text { The usefulness of big data analytics to support smart destinations by studying the } \\
\text { online image of as transmitted via social media. }\end{array}$ \\
\hline Neirotti et al. [56] & 2016 & $\begin{array}{l}\text { The role of social media data such as user-generated reviews on TripAdvisor, for } \\
\text { value creation among tourism firms (hotels) }\end{array}$ \\
\hline Miah et al. [67] & 2016 & $\begin{array}{l}\text { The analysis of Big data generated across social media sites for destination } \\
\text { management organization's decision support. }\end{array}$ \\
\hline Encalada [60] & 2017 & $\begin{array}{l}\text { Understanding the consumption of space within urban tourist destinations } \\
\text { through the analysis of the spatial distribution of tourists in the city based on data } \\
\text { collected from social networks. }\end{array}$ \\
\hline Hu et al. [73] & 2017 & $\begin{array}{l}\text { Use of specific big data analytics techniques such as opinion mining of Online } \\
\text { travel forums and social networks to provide tourism actors (such as hotels) with } \\
\text { more comprehensive information. }\end{array}$ \\
\hline Polese et al. [62] & 2018 & $\begin{array}{l}\text { The role of social media data for managing and optimizing tourism value } \\
\text { co-creation and for transitioning to social innovation. }\end{array}$ \\
\hline
\end{tabular}

Despite this, the comprehension of how Big Data can be opportunely used to sustain the innovation process of tourism destination has still received little consideration. Accordingly, this paper aims to shed new light on the role that social Big Data can have in nurturing strategies of open innovation in tourism by focusing on social networks as enabling platforms for tourists' involvement, contributing to sustainability and competitiveness.

\section{Methodology}

This paper adopts a longitudinal single case study methodology. As argued by Yin [74,75], a single case study is appropriate to monitor in depth a contemporary event and behavior that cannot be controlled, as well as to derive theory from contemporary phenomena within a real setting. The longitudinal perspective of analysis has been conducted for a period of three months over three years (2015-2017). The collection, analysis and reporting of different data, allows us to derive a comprehension of the event as well as to register its evolutionary patterns and results. The findings obtained are of extreme usefulness for the comprehension of usage of Social Big Data for the innovative conception and management of a destination offering according to the open paradigm.

The case study is addressed by different explorative approaches and tools for social Big Data retrieval and analysis [18].

\subsection{The Research Context}

The context of analysis is identified in Bacco nelle Gnostre, a well-recognized annual event that started in 1999 (in 2017 it was the 18th edition) for celebrating the agrofood and culinary tradition of Noci, an inland small town located in the Murgia of Trulli, province of Bari (Apulia, Southern Italian Region) and that was livened up by music, street artists and several cultural initiatives.

Following the case study guidelines set out by Yin $[74,76]$, the case was developed to demonstrate how the management of social Big Data could be useful for creating value for the open innovation process and for sustainable growth of a tourism destination. 
The longitudinal study conducted covers the last three editions, from 2015 to 2017. The case has been developed in terms of nature of tourist experience, area, period, promoter, partners and official hashtags identified as keywords for the business analytics, are provided in the following table (Table 2).

Table 2. "Bacco nelle Gnostre" case description.

\begin{tabular}{|c|c|c|c|}
\hline Main Info & 2015 & 2016 & 2017 \\
\hline Period of experience & November $7-8$ & November 5-6 & November $11-12$ \\
\hline $\begin{array}{l}\text { Nature of the experience } \\
\text { as official presented }\end{array}$ & \multicolumn{3}{|c|}{$\begin{array}{l}\text { Festival of new wine and roast chestnuts, in Noci a province of Bari, livened up by } \\
\text { music, street artists and several cultural initiatives. }\end{array}$} \\
\hline $\begin{array}{l}\text { Geographical area } \\
\text { interested by }\end{array}$ & \multicolumn{3}{|c|}{ South of Italy-Noci (Bari). } \\
\hline Promoter of the initiative & \multicolumn{3}{|c|}{$\begin{array}{l}\text { Associazione Culturale ACUTO_Parco Letterario Formiche di } \\
\text { Puglia-“Tommaso Fiore". }\end{array}$} \\
\hline Other partners & \multicolumn{3}{|c|}{$\begin{array}{l}\text { Laboratory of Management Engineering of the University of Salento (Italy), } \\
\text { NociMydestination association, Institutional Partners (regional tourist agencies, } \\
\text { municipalities, etc.), IGERs Communities, Technical Partners (agro-food } \\
\text { companies, hotels, etc.). }\end{array}$} \\
\hline $\begin{array}{c}\text { Number and nature of } \\
\text { storytellers }\end{array}$ & \multicolumn{3}{|c|}{$\begin{array}{l}2 \text { (one individual not professional and one belonging to an association for } \\
\text { destination management). }\end{array}$} \\
\hline Estimated attendees & \multicolumn{3}{|c|}{ More than 100.000 with an increasing trend } \\
\hline
\end{tabular}

The event Bacco nelle Gnostre is promoted by a non-profit organization operating in the cultural field. It leverages a wide community of stakeholders such as the Laboratory of Management Engineering at the University of Salento (Lecce, Italy), local firms, IGERs (Instagrammers) Communities, and other agencies and associations. Strategic actors' involvement has produced positive results in terms of organization of the digital campaign, visibility and follow-ups.

Specifically, in the three editions, two main storytellers have been involved: One is a socially addicted individual and the other one is the official account of a local destination management association (Nocimydestination association). Every day the storytellers published in their social media pages photo, video and posts in order to promote the events, to attract tourists and to increase their involvement in the valorization of the destination.

\subsection{Data Collection}

The data collection phase, aimed to gather social Big Data related to the event and shared on the official social network profile, has been realized in the period from September to November of each year. The Laboratory of Management Engineering of the University of Salento has been actively involved in supporting the social media team of the event's organizers. In particular, its contribution has regarded the awareness creation, setting of communication strategy (in terms of \#, contents, storytellers, etc.), gathering, processing and analysis of data.

Data have been collected from primary sources identified in official websites and social profiles. Semi-structured interviews have been addressed to key informants [77] to receive inputs for analytics and deepen specific issues related to the variables analyzed. In each edition, four interviews have been addressed to key informants, identified into the legal representative and the social media manager of the association promoting the event (Associazione Acuto) and the legal representative and the marketing responsible of the local destination management association (NociMyDestination); accordingly the total interviews conducted were $12(4 \times 3)$, with a duration ranging from 35 to $45 \mathrm{~min}$. Open-ended questions were defined in order to investigate the role of social Big Data in the organization of the events and the open innovation process. Key informants are invited to describe the characteristics of the events, the partnership, the digital strategy, followed by questions regarding 
customer satisfaction monitoring and involvement and the use of business analytics evidence to redefine the strategy of the events or to make corrective actions. The interviews were conducted through a semi-structured protocol composed by three sections: A general overview of the initiative observed; actions and strategies for tourists' involvement and satisfaction; return on data collected from the business analytics (Appendix A).

Data collected from social analytics and interviews have been processed through iteration with the literature background [78-80].

\subsection{Data Analysis}

Data analysis was performed following the phases of business analytics defined by Chen et al. [18], from data collections, extractions, analysis and visualization, considered as a set of sub processes in the overall process of "insight extraction" from Big Data [1].

This process could be summarized as: Generate, analyze and get insights. Business analytics of social Big Data of the three main social networks (Facebook, Twitter and Instagram) was performed through two kinds of tools: Keyhole (free version) and Buzztrack (proprietary tool). Both the tools have preliminarily requested the setting of parameters for extracting data (official profiles, accounts and keywords (\#), observation time, kind of channel to monitor etc.).

Keyhole is a tool that is used for comprehending Instagram and Twitter data. It provides a visual analysis of data and statistics related to socio-demographics, users' behaviors, timeline, topics of interests, top influences, sources of access, clustering in the form of a tag cloud, etc.

Buzztrack is a machine-learning tool working on data from pre-defined Facebook pages and Twitter accounts. It classifies textual information streams to define the associated "sentiment". Different kinds of dashboards related to the sentiment were visualized at the end of the process.

All the digital contents published on Facebook, Twitter and Instagram (posts, tweet/retweets, comments, replies, photo and video) with the keyword identified (\#) during the monitoring period were extracted and analyzed with different kinds of dashboard. Specifically, the analysis along the three editions focused on common (\#bacconellegnostre, \#gnostrenoci, \#nocimydestination, \#ilpaninodibacco, \#ilovebacco), and distinctive hashtags (i.e., \#bacco2016, \#bacconellegnostre 2016) and on the basis of the most common variables and key performance indicators (KPIs) used for business analytics and social media listening. They have identified the reach and impressions as measures of the number of potential and audience reached by the digital tracks, number of posts and comments on social media platforms, and also considered the most influential, socio-demographics, in terms of geographic location and gender, types of devices adopted, tag cloud and sentiment, as results of recurrence of words used for describing the experience.

\section{Findings}

The results emerging from the Social Big Data analytics of the three editions of Bacco nelle Gnostre allow to derive evidence for the comprehension of opportunities in terms of open innovation and sustainability of a Tourism Destination. In all the editions, social networks have been adopted as enabling platforms of interaction with tourists and as virtual spaces to share feedbacks and information. For this, they are configurable as a repository of strategic knowledge assets resulting from the inbound and outbound flows of data enabled and sources of inspiration for businesses and organizations, as well as for tourists.

In Table 3, the results obtained in terms of social analytics metrics were detailed for each edition on the basis of the most popular hashtag associated to it. 
Table 3. "Bacco nelle Gnostre" at the glance.

\begin{tabular}{|c|c|c|c|}
\hline Variables & 2015 & 2016 & 2017 \\
\hline Hashtag & \#bacconellegnostre2015 & \#bacco2016 & \#bacconellegnostre \\
\hline Reach & 122.710 & 24.183 & 177.909 \\
\hline Impressions & 261.512 & 110.541 & 159.080 \\
\hline $\begin{array}{l}\text { Nr. of Post, Comments } \\
\text { and replies on Facebook }\end{array}$ & 222 & 318 & 89 \\
\hline Tot. Nr. of Tweets & 8 & 38 & 18 \\
\hline $\begin{array}{l}\text { Tot. Nr. of Posts and } \\
\text { Comments on Instagram }\end{array}$ & 241 & 141 & 390 \\
\hline $\begin{array}{l}\text { Social Network more } \\
\text { influent }\end{array}$ & Instagram & Facebook & Instagram \\
\hline Geographic coverage & Italy & Italy & Italy \\
\hline Gender \% & $\begin{array}{l}66 \% \text { Female } \\
34 \% \text { Male }\end{array}$ & $\begin{array}{l}92 \% \text { Female } \\
8 \% \text { Male }\end{array}$ & $\begin{array}{l}76 \% \text { Female } \\
33 \% \text { Male }\end{array}$ \\
\hline $\begin{array}{l}\text { Main Types of devices } \\
\text { used }\end{array}$ & $\mathrm{n} / \mathrm{a}$ & Mobile/Iftt & Desktop/Web \\
\hline Tag Cloud & $\begin{array}{l}\text { bellezza, noci, vicoli, } \\
\text { tradizione, food, viaggio, } \\
\text { nocidamare, love }\end{array}$ & $\begin{array}{l}\text { noci, igerspuglia, } \\
\text { igersvalleditria, } \\
\text { nocimydestination, } \\
\text { noci24, food }\end{array}$ & $\begin{array}{c}\text { puglia, noci, bacco, } \\
\text { foodporn, igerspuglia, } \\
\text { wine, sagra, tradizione, } \\
\text { vino, panino }\end{array}$ \\
\hline Sentiment & $\begin{array}{l}60 \% \text { Neutral } \\
39 \% \text { Positive } \\
1 \% \text { Negative }\end{array}$ & $\begin{array}{l}52 \% \text { Neutral } \\
47 \% \text { Positive } \\
1 \% \text { Negative }\end{array}$ & $\begin{array}{l}63 \% \text { Positive } \\
35 \% \text { Neutral } \\
2 \% \text { Negative }\end{array}$ \\
\hline
\end{tabular}

The Figure 1 provides a synthesis of the main outputs of business analytics performed by the tool Keyhole and is related to one of the editions analyzed (2016). It is organized as a collection of the dashboards obtained and is based on the main key performance indicators (KPIs) for social media analytics as defined above into the methodology.

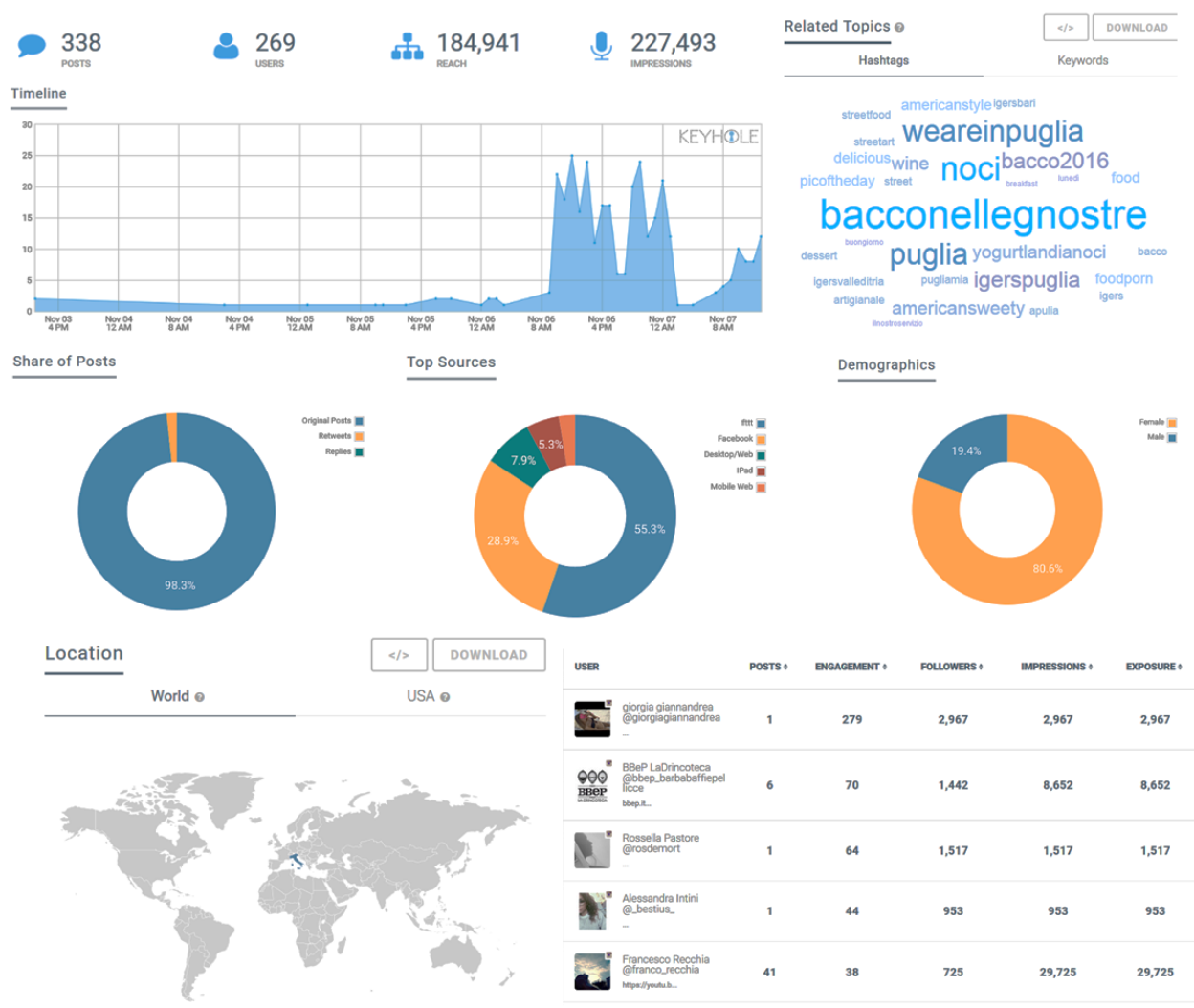

Figure 1. Keyhole Business analytics. 
The Figure 2 presents the results of the sentiment analysis performed through the Buzztrack tool for the 2016 edition. In the pie charts, the ratios of positive/negative/neutral sentiment resulting from contents published with almost one of the events' hashtags (\#BACCO2016 or \#bacconellegnostre for Bacco nelle Gnostre 2016) are presented. In the timelines, the temporal evolution of the sentiments registered is described.
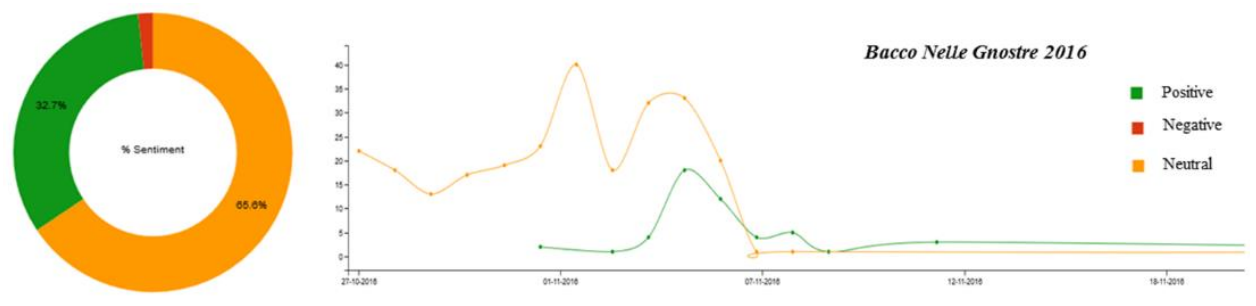

Figure 2. Buzztrack Sentiment Analysis.

The results of the interviews conducted with key informants has allowed to acquire further complementary information useful to identify specific feature of the event, such as the valorization of the agrofood and culinary tradition of the City of Noci as well as the beauties of the old town; the reasons behind the period chosen, that in Bacco nelle Gnostre is the beginning of the autumn in the early November, concurrently with the Novello wine that is one of the main feature of the event; the strategy of storytellers' involvement, with social addicted and local expert; dynamics and trends of collaboration activated at local level, with evidence of the large and growing interest of the local tourism and agrofood entrepreneurs; role, level of awareness and strategies behind the usage of social networks in the valorization of the tourism experiences, as well as qualitative feedbacks on the processes of improvement realized across the three editions.

From a smart tourism perspective, the findings support the assumption that social Big Data is an important component of Tourism destination since it can contribute to making more efficient decision-making, innovating the offering of tourist experiences, monitoring and managing tourists' involvement and satisfaction by contributing to enhance the smart and sustainable growth of destination [60].

\section{Discussion}

The longitudinal analysis of the case study discloses interesting evidence about open innovation opportunities emerging in context of tourism destination management. This is because the knowledge flows generated on and about a local experience through the web and social media by tourists can nurture the Social Big Data related to the destination by allowing us to identify trends of satisfaction, critical issues and problems, areas of immediate interventions, opportunities of development and personalization of the tourism offering according to criteria of gender, geographical location, technological devices, etc. Evidence collected in the study through business analytics and interviews demonstrate that the management of Social Media Big Data in Smart Tourism can sustain the value creation process of destinations and tourism organizations by allowing us to nurture a strategy of open innovation in all three main stages, as suggested by Mount and Garzia Martinez's framework [8] previously recalled. The data collected result is to be coherent with the different data sources and categories defined by Li et al. [16] in the comprehensive framework related to the review of research on Big Data in Tourism. The Figure 3 offers a synthetic contribution about the evidence collected by clustering the main variables around the three open innovation phases of Ideation, R\&D and Commercialization. 


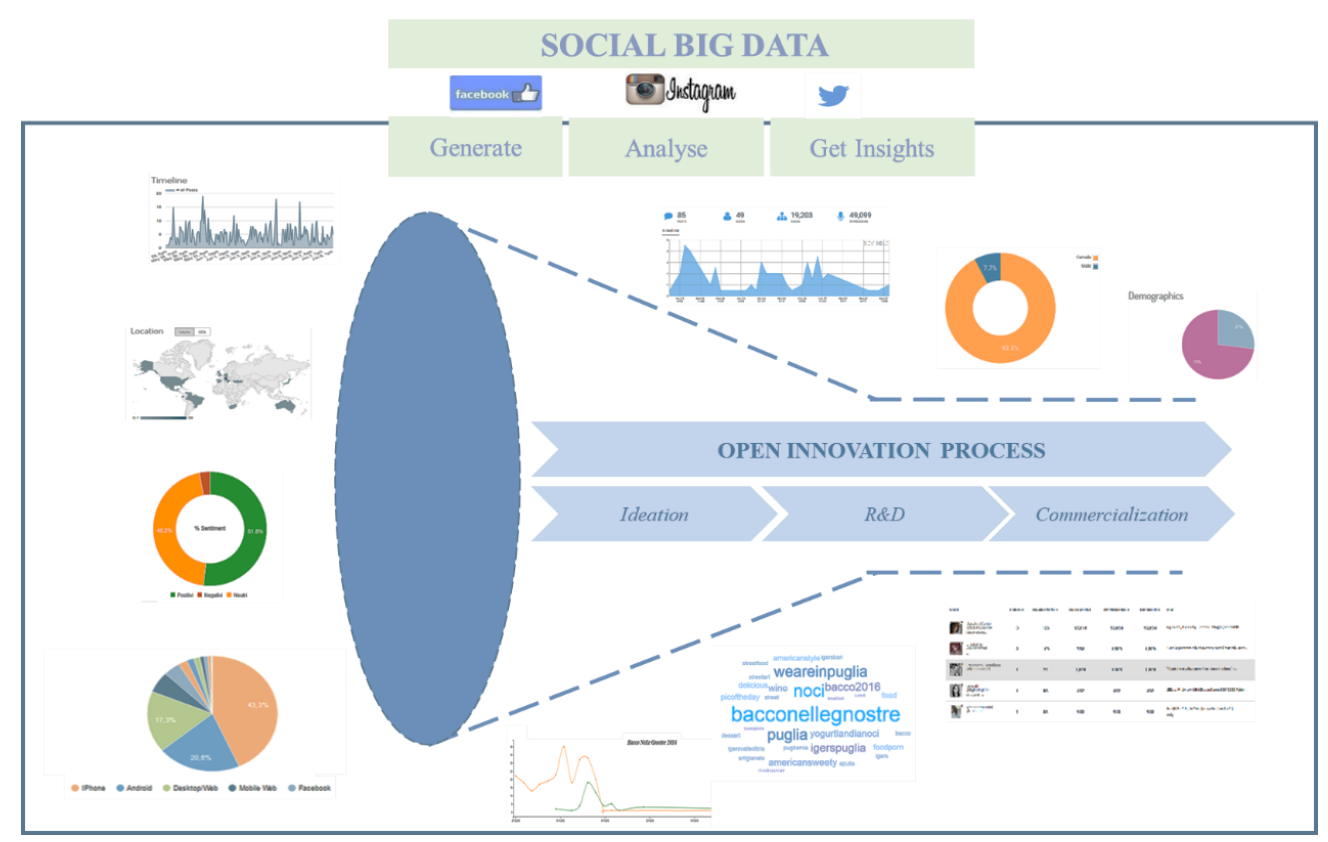

Figure 3. Social Big Data and Open Innovation Process.

Starting from the Ideation stage, Social Media Big Data can disclose several opportunities of innovation of the tourism offering by harnessing the power of the crowd and allowing events' organizers and destination makers to grasp the benefits of a collaborative and distributed process of idea generation. Analysis related to tag cloud, geographical coverage, main devices used or type of most appreciated post can generate valuable insights for the ideation phase. In tag clouds, the analysis of the words that are more frequently used by the tourists in their posts could represent a valid source of external knowledge for the destination makers useful for the identification of new market and new opportunities. In the case of Bacco nelle Gnostre 2016 the monitoring of social media data enabled the identification not only of the critical areas to be performed (accessibility, garbage, price), but also the discovering of the main assets that are more appreciated by the tourists. Themes such as "culture" and "entertainment" suggested to the organizers the idea of creating, for the future editions, an integrated touristic package composed of a set of different assets: Agro-food, nature and culture, and entertainment (for example Noci's folk festival).

The second stage of open innovation process refers to the R\&D stage for sustaining the development of new products and services. Social Media Big Data can allow us to define customers' profiles, the identification of behaviors and needs, and the creation of a personalized tourist offering. Additionally, the monitoring of users' experiences as well as the creation by themselves of experiential packages around the events promoted is an additional source of value for the goal of this second phase. Business analytics provides tourism organizers with the opportunity to anticipate customer expectations and to predict the market's needs. The study of the variables that allowed the definition of tourists' profiles, such as socio-demographic categories, can be used to assess the attractiveness of local experiences and can be the basis for the R\&D phase in order to create a new offering.

This electronic word-of-mouth could be useful to re-define the future conception and development of the event. The recurrence of positive keyword (magnificent, nice, etc.) can support organizers in validating their offering, in assuming decisions for future initiatives.

The case analysis demonstrated that social Big Data are meaningful sources for the development of local destinations in a sustainable way. In all the editions analyzed, the results of business analytics that social media can disclose market opportunities for a not conventional tourism offering based on the valorization of natural, cultural, and agro-food assets with large implications for the environmental, societal and economic growth. 
The process innovation also regards the development of new business models and strategies related to the new configuration of tourism demand and supply.

Regarding to the third stage of the open innovation process (commercialization), social media constitute a relevant promotional and marketing channel and a strong word-of-mouth that can drive marketing of products and services though peer-recommendations. The performances registered for the official hashtags confirm the growing popularity of events and the creation of a stable relationship among organizers and the tourist community. Social Big Data analysis has contributed to a deepened comprehension of what tourists need, to create involvement and trust. They also confirmed that the involvement of top influencers as official storytellers can positively contribute to the success of initiative, create awareness and a shared culture of sustainable consumption.

This is coherent with what has been found in other studies, such as in the study of Encalada et al. [60] where enhanced information access in combination with the high interest of tourist to produce online content and to share information on social media, allows for a better understanding of tourist behavior and therefore decision-makers to imagine new patterns for a sustainable and smart growth.

\section{Conclusions}

The adoption of social Big Data offers several opportunities for the open innovation and for the sustainable growth of tourism destinations. By confirming the relevance of Big Data as a source of Open Innovation and critical factor for a Smart Destination, the paper demonstrated how it is possible to leverage on social networks, that in activating closer interactions and users' involvement, operate as valuable sources of data by allowing tourism destinations to innovate their offering of local experiences in an open and collaborative way.

The study offers implications both for theory and practice. As for theory, the open innovation perspective adopted for describing research findings represents an original contribution at the recent debate on management of social Big Data with a specific focus on Smart Tourism. This suggests the opportunities of deepening with theoretical and practical contributions are the issue in order to derive interpretive and analytical frameworks. As for the practice, two main implications arise for destination makers and tourism organizations, both private and public. The study highlights how social Big Data can support the process of value creation and the competitiveness of destinations through open and collaborative innovation strategies. This calls for a renewed culture and competences and skills both at the organizational and destination level. A second implication arises for the political agendas of destinations that are called to innovate their programs and instruments for the development in order to compete at global level, by embracing social Big Data for affording the challenges of a sustainable growth.

Limitations and future research. As in all studies, this article presents some limitations. Specifically, in providing an original contribution to the identification of opportunities for open innovation and sustainability in tourism through social Big Data, the paper presents limitations related to the context of analysis, in terms of industry and geographic area, and also in terms of number of posts published on social network platforms that have been analyzed. Accordingly, it could be useful to replicate the study in different productive sectors, to identify industrial patterns, as well as in different destinations, or tourism events with a higher promotion and engagement on social network, to find trends at local and general level for the sustainability and growth of tourism destination.

In both the future developments, the replication of the analysis will allow us to consolidate the identification of trends and opportunities for the open innovation resulting from Big Data and to derive implications for the competitiveness and sustainable growth of organizations and territories. A further development of the research could focus on the analysis of different types of Big Data (i.e., data generated through sensors, etc. and related to the Internet of Things) to integrate evidence coming from business analytics or identify new patterns for methodological and empirical contributions. Additionally, a future element of investigation could be related to the socio-demographic trends (i.e., gender, locations, etc.) deriving from the business analytics. Finally, 
focusing on the cross-disciplinary nature of the study, as resulting from both the theoretical and empirical frameworks, the paper identifies roots for future investigation under different perspectives, such as business management, IT management, tourism management, environmental sustainability and regional smart growth.

Author Contributions: All the authors have equally contributed to this paper. Specifically, Pasquale Del Vecchio has conceived and designed the longitudinal case study, the conceptualization of the study, the findings and the overall original draft. Gioconda Mele has analyzed the case, collected data, and written the original draft. Valentina Ndou has mainly contributed to the theoretical background, supervised the conceptual development and written the original draft. Giustina Secundo has mainly contributed to the introduction, discussion and conclusions, reviewing, editing the final version.

Funding: This research received no external funding.

Conflicts of Interest: The authors declare no conflict of interest.

\section{Appendix A}

Table A1. Semi-structured interview.

\begin{tabular}{|c|c|}
\hline \multicolumn{2}{|r|}{ Questions } \\
\hline $\begin{array}{l}\text { General overview of the } \\
\text { initiative }\end{array}$ & $\begin{array}{l}\text { - Can you offer a brief description of event in terms of: nature of tourism } \\
\text { experience, history of the events, programs, calendar, partnerships and } \\
\text { collaboration, time required to organize the event; number of attendees in } \\
\text { the past edition? }\end{array}$ \\
\hline $\begin{array}{l}\text { Actions and strategies for } \\
\text { tourist's involvement and } \\
\text { satisfaction }\end{array}$ & $\begin{array}{l}\text { - Which promotional strategy is being used most frequently by your } \\
\text { association for the event? } \\
\text { - Do you have an official social media page for the promotions of the event? } \\
\text { If yes, specify the social media platforms. } \\
\text { Does your organisation engage in market research to study consumer } \\
\text { needs and wants? } \\
\text { During the events, your association survey customers about their opinions } \\
\text { of the organization's effort? } \\
\text { - Have you developed apps or digital content related to the events? } \\
\text { How open is your company for new ideas and innovation suggest by } \\
\text { events participants? }\end{array}$ \\
\hline $\begin{array}{l}\text { Return on data collected from the } \\
\text { business analytics }\end{array}$ & $\begin{array}{l}\text { - Do you collect and analyze social media posts that attendees leave on } \\
\text { official social media page of the event? } \\
\text { - Do you have property or open source tool for analyze social } \\
\text { media contents? } \\
\text { - How the evidence coming from business analytics performed by the } \\
\text { University for the past editions, supported your association in the } \\
\text { definition of the future initiatives? } \\
\text { Business analytics activities supports yours association in enhancing the } \\
\text { tourism offering and customer satisfaction? }\end{array}$ \\
\hline
\end{tabular}

\section{References}

1. Gandomi, A.; Haider, M. Beyond the hype: Big data concepts, methods, and analytics. Int. J. Inform. Manag. 2015, 35, 137-144. [CrossRef]

2. Del Vecchio, P.; Mele, G.; Ndou, V.; Secundo, G. Creating value from Social Big Data: Implications for Smart Tourism Destinations. Inform. Process. Manag. 2018, 54, 847-860. [CrossRef]

3. Laney, D. 3D data management: Controlling data volume, velocity and variety. META Group Res. Note 2001, 6, 1. Available online: https://blogs.gartner.com/doug-laney/files/2012/01/ad949-3D-Data-ManagementControlling-Data-Volume-Velocity-and-Variety.pdf (accessed on 2 July 2018).

4. Schutt, R.; O'Neil, C. Doing Data Science: Straight Talk from the Frontline; O'Reilly Media: Beijing, China, 2013.

5. Jin, X.; Wah, B.W.; Cheng, X.; Wang, Y. Significance and challenges of big data research. Big Data Res. 2015, 2, 59-64. [CrossRef] 
6. De Mauro, A.; Greco, M.; Grimaldi, M. A formal definition of Big Data based on its essential features. Libr. Rev. 2015, 65, 122-135. [CrossRef]

7. Brodie, R.J.; Ilic, A.; Juric, B.; Hollebeek, L. Consumer Engagement in a virtual brand community: An exploratory analysis. J. Bus. Res. 2013, 66, 105-114. [CrossRef]

8. Mount, M.; Garzia Martinez, M.G. Social media. Calif. Manag. Rev. 2014, 56, 124-143. [CrossRef]

9. Brunswicker, S.; Vanhaverbeke, W. Open innovation in small and medium-sized enterprises (SMEs): External knowledge sourcing strategies and internal organizational facilitators. J. Small Bus. Manag. 2015, 53, 1241-1263. [CrossRef]

10. Linders, D. From E-Government to We-Government: Defining a typology for citizen coproduction in the age of social media. Gov. Inform. Q. 2012, 29, 446-454. [CrossRef]

11. Buhalis, D.; Amaranggana, A. Smart tourism destinations. In Information and Communication Technologies in Tourism; Xiang, Z., Tussyadiah, I., Eds.; Springer: Dublin, Ireland, 2014; pp. 553-564.

12. Buhalis, D. Marketing the competitive destination of the future. Tour. Manag. 2000, 21, 97-116. [CrossRef]

13. Buhalis, D.; Law, R. Progress in tourism management: Twenty years on and 10 years after the internet: The state of eTourism research. Tour. Manag. 2008, 29, 609-663. [CrossRef]

14. Brown, B.; Chui, M.; Manyika, J. Are you ready for the era of "Big Data"? McKinsey Q. 2011, 4, $24-35$.

15. LaValle, S.; Lesser, E.; Shockley, R.; Hopkins, M.S.; Kruschiwtz, N. Big Data, analytics and the path from insight to value. MIT Sloan Manag. Rev. 2011, 52, 21-32.

16. Li, J.; Xu, L.; Tang, L.; Wang, S.; Li, L. Big data in tourism research: A literature review. Tour. Manag. 2018, 68, 301-323. [CrossRef]

17. Bello-Orgaz, G.; Jung, J.J.; Camacho, D. Social big data: Recent achievements and new challenges. Inform. Fusion 2016, 28, 45-59. [CrossRef]

18. Chen, H.; Chiang, R.H.; Storey, V.C. Business intelligence and analytics: From Big Data to big impact. MIS Q. 2012, 36, 1165-1188.

19. Hall, J.; Wagner, M. Integrating sustainability into firms' processes: Performance effects and the moderating role of business models and innovation. Bus. Strateg. Environ. 2012, 21, 183-196. [CrossRef]

20. Hart, S.L.; Milstein, M.B. Creating sustainable value. Acad. Manag. Perspect. 2003, 17, 56-67. [CrossRef]

21. World Tourism Organization (UNWTO); United Nations Environmental Programme (UNEP). Making Tourism More Sustainable: A Guide for Policy-Makers; World Tourism Organization Publications: Madrid, Spain, 2005.

22. Crotti, R.; Misrahi, T. (Eds.) World Economic Forum the Travel \& Tourism Competitiveness Report 2015. Growth through Shocks. World Economic Forum: Geneva, Switzerland, 2015. Available online: http:/ /www3.weforum. org/docs/TT15/WEF_Global_Travel\&Tourism_Report_2015.pdf (accessed on 2 July 2018).

23. Iunius, R.F.; Cismaru, L.; Foris, D. Raising competitiveness for tourist destinations through information technologies within the newest tourism action framework proposed by the European commission. Sustainability 2015, 7, 12891-12909. [CrossRef]

24. Ward, J.S.; Barker, A. Undefined by Data: A survey of Big Data Definitions. arXiv 2013, arXiv:1309.5821.2013. Available online: https: / / arxiv.org/abs/1309.5821(accessed on 2 July 2018).

25. Davenport, T.H. How strategists use "big data" to support internal business decisions, discovery and production. Strat. Leadersh. 2014, 42, 45-50. [CrossRef]

26. McAfee, A.; Brynjolfsson, E. Big data. The management revolution. Harv. Bus. Rev. 2012, 90, 60-68. Available online: https:/ /hbr.org/2012/10/big-data-the-management-revolution (accessed on 7 September 2018). [PubMed]

27. Manyika, J.; Chui, M.; Brown, B.; Bughin, J.; Dobbs, R.; Roxburgh, C.; Hung Bayers, A. Big Data: The Next Frontier for Innovation, Competition, and Productivity; McKinsey Global Institute: Washington, DC, USA, 2011.

28. George, G.; Haas, M.R.; Pentland, A. “Big data and management”. Acad. Manag. J. 2014, 57, $321-326$. [CrossRef]

29. Ndou, V.; Beqiri, M. Introduction for the special Issue on BIG DATA. Electro. J. Appl. Stat. Anal. 2014, 5, 1-3.

30. Chesbrough, H. Open Innovation Business Models; How to Thrive in the Innovation Landscape; Harvard Business School Press: Boston, MA, USA, 2006.

31. Chesbrough, H. Open Innovation; Harvard Business School Publishing: Boston, MA, USA, 2003.

32. Gatignon, H.; Tushman, M.L.; Smith, W.; Anderson, P. A structural approach to assessing innovation: Construct development of innovation locus, type, and characteristics. Manag. Sci. 2002, 48, 1103-1122. [CrossRef] 
33. Hauser, J.; Tellis, G.J.; Griffin, A. Research on innovation: A review and agenda for marketing science. Mark. Sci. 2006, 25, 687-717. [CrossRef]

34. Natalicchio, A.; Ardito, L.; Savino, T.; Albino, V. Managing knowledge assets for open innovation: A systematic literature review. J. Knowl. Manag. 2017, 21, 1362-1383. [CrossRef]

35. Von Hippel, E. Democratizing Innovation; MIT press: Cambridge, MA, USA, 2005.

36. Del Vecchio, P.; Di Minin, A.; Petruzzelli, A.M.; Panniello, U.; Pirri, S. Big data for open innovation in SMEs and large corporations: Trends, opportunities, and challenges. Creat. Innov. Manag. 2018, 27, 6-22. [CrossRef]

37. Ndou, V.; Del Vecchio, P.; Mele, G.; Stefanizzi, P.; Passiante, G. Measuring the promptness of destinations to move toward a smart tourism configuration: The case of Apulia destination. In Proceedings of the 27th International Business Information Management Association Conference-Innovation Management and Education Excellence Vision 2020: From Regional Development Sustainability to Global Economic Growth, IBIM, Milano, Italia, 2016; pp. 3021-3031.

38. Mayer-Schönberger, V.; Cukier, K. Big Data: A Revolution That Will Transform How We Live, Work, and Think; Eamon, D., Ed.; Houghton Mifflin Harcourt: Boston, MA, USA, 2013.

39. Kaisler, S.; Armour, F.; Espinosa, J.A.; Money, W. Big data: Issues and challenges moving forward. In Proceedings of the 46th Hawaii International Conference on System Sciences, Wailea, HI, USA, 7-10 January 2013; pp. 995-1004.

40. Schadt, E.E.; Linderman, M.D.; Sorenson, J.; Lee, L.; Nolan, G.P. Computational solutions to large-scale data management and analysis. Nat. Rev. Genet. 2010, 11, 647-657. Available online: http:/ /dx.doi.org/10.1038/ nrg2857 (accessed on 5 June 2018). [CrossRef] [PubMed]

41. Davenport, T.H.; Barth, P.; Bean, R. How 'big data' is different. MIT Sloan Manag. Rev. 2012. Available online: https:/ / sloanreview.mit.edu/article/how-big-data-is-different/ (accessed on 5 June 2018).

42. Griffin, R. Using Big Data to combat enterprise fraud: To combat fraud, more organizations are thinking big-Employing new approaches around Big Data to convert the volumes of information available into useful insight and real action. Financ. Exec. 2012, 28, 44-48.

43. Wagner, E. Realities learning professionals need to know about analytics. $T$ E D 2012, 66, 54-58.

44. Safko, L. The Social Media Bible: Tactics, Tools, and Strategies for Business Success, 3rd ed.; John Wiley \& Sons, Inc.: Hoboken, NJ, USA, 2012.

45. Shaw, G.; Williams, A. Knowledge transfer and management in tourism organisations. Tour. Manag. 2009, 30, 325-335. [CrossRef]

46. Sheehan, L.; Sánchez, A.V.; Presenza, A.; Abbate, T. The Use of Intelligence in Tourism Destination Management: An Emerging Role for DMOs. Int. J. Tour. Res. 2016, 18, 549-557. [CrossRef]

47. Shapiro, J.M. Smart cities: Quality of life, productivity, and the growth effects of human capital. Rev. Econ. Stat. 2006, 88, 324-335. [CrossRef]

48. Caragliu, A.; Del Bo, C.; Nijkamp, P. Smart Cities in Europe. J. Urban Technol. 2011, 18, 65-82. [CrossRef]

49. Wang, D.; Xiang, Z. The new landscape of travel: A comprehensive analysis of smartphone apps. In Information and Communication Technologies in Tourism; Springer: New York, NY, USA, 2012; pp. 308-319.

50. Micera, R.; Presenza, A.; Splendiani, S.; Del Chiappa, G. Smart destinations: New strategies to manage tourism industry. In Proceedings of the International Forum on Knowledge Asset Dynamics, Zagreb, Croatia, June 2013. Available online: https:/ / doctiktak.com/smart-destinations.html (accessed on 5 July 2018).

51. Buhalis, D.; Amaranggana, A. Smart Tourism Destinations Enhancing Tourism Experience through Personalisation of Services. In Information and Communication Technologies in Tourism 2015; Tussyadiah, I., Inversini, A., Eds.; Springer: Cham, Switzerland, 2015. Available online: https://link.springer.com/chapter/ 10.1007/978-3-319-14343-9_28\#citeas (accessed on 20 June 2018).

52. Sigala, M.; Christou, E.; Gretzel, U. Web2.0 in Travel, Tourism and Hospitality. Theory, Practice and Cases; Ashgate Publishers: Farnham, UK, 2012.

53. Law, R.; Buhalis, D.; Cobanoglu, C. Progress on information and communication technologies in hospitality and tourism. Int. J. Contemp. Hosp. 2014, 727-750. [CrossRef]

54. Presenza, A.; Micera, R.; Splendiani, S.; Del Chiappa, G. Stakeholder e-involvement and participatory tourism planning: Analysis of an Italian case study. Int. J. Knowl. Base. Dev. 2014, 5, 311-328. [CrossRef]

55. Xiang, Z.; Schwartz, Z.; Gerdes, J.H.; Uysal, M. What can big data and text analytics tell us about hotel guest experience and satisfaction? Int. J. Hosp. Manag. 2015, 44, 120-130. [CrossRef] 
56. Neirotti, P.; Raguseo, E.; Paolucci, E. Are customers' reviews creating value in the hospitality industry? Exploring the moderating effects of market positioning. Int. J. Inform. Manag. 2016, 36, 1133-1143. [CrossRef]

57. Nam, T.; Pardo, A.T. Conceptualizing smart city with dimensions of technology, people, and institutions. In Proceedings of the 12th Conference on Digital Government Research, College Park, MD, USA, 12-15 June 2011.

58. Del Vecchio, P.; Passiante, G. Is tourism a driver for smart specialization? Evidence from Apulia, an Italian region with a tourism vocation. J. Destin. Mark. Manag. 2017, 6, 163-165. [CrossRef]

59. Albino, V.; Berardi, U.; Dangelico, M.R. Smart cities: Definitions, dimensions, performance and initiatives. J. Urban Technol. 2015, 22, 3-21. Available online: http:/ / dx.doi.org/10.1080/10630732.2014.942092 (accessed on 7 September 2018). [CrossRef]

60. Encalada, L.; Boavida-Portugal, I.; Cardoso Ferreira, C.; Rocha, J. Identifying tourist places of interest based on digital imprints: Towards a sustainable smart city. Sustainability 2017, 9, 2317. [CrossRef]

61. Tu, Q.; Liu, A. Framework of smart tourism research an related progress in China. In Proceedings of the International Conference on Management and Engineering, Shanghai, China, 24-25 May 2014; pp. 140-146.

62. Polese, F.; Botti, A.; Grimaldi, M.; Monda, A.; Vesci, M. Social innovation in smart tourism ecosystems: How technology and institutions shape sustainable value co-creation. Sustainability. 2018, 10, 140. [CrossRef]

63. Gretzel, U.; Sigala, M.; Xiang, Z.; Koo, C. Smart tourism: Foundations and developments. Electron. Mark. 2015, 25, 179-188. [CrossRef]

64. Chung, N.; Tyan, I.; Chung, H.C. Social support and commitment within social networking site in tourism experience. Sustainability 2017, 9, 2102. [CrossRef]

65. Neuhofer, B.; Buhalis, D.; Ladkin, A. Conceptualising technology enhanced destination experiences. J. Destin. Mark. Manag. 2012, 1, 36-46. [CrossRef]

66. d'Hauteserre, A.M. Lessons in managed destination competitiveness: The case of Foxwoods Casino Resort. Tour. Manag. 2000, 21, 23-32. [CrossRef]

67. Miah, S.J.; Vu, H.Q.; Gammack, J.; McGrath, M. A big data analytics method for tourist behaviour analysis. Inform. Manag. 2016, 54, 771-785. [CrossRef]

68. Buhalis, D.; Foerste, M. SoCoMo marketing for travel and tourism: Empowering co-creation of value. J. Destin. Mark. Manag. 2015, 4, 151-161. [CrossRef]

69. Khan, N.; Yaqoob, I.; Hashem, I.A.T.; Inayat, Z.; Mahmoud Ali, W.K.; Alam, M.; Gani, A. Big data: Survey, technologies, opportunities, and challenges. Sci. World J. 2014. Available online: https://www.hindawi. com/journals/tswj/2014/712826/abs/ (accessed on 2 July 2018). [CrossRef] [PubMed]

70. Fuchs, M.; Höpken, W.; Lexhagen, M. Big data analytics for knowledge generation in tourism destinations-A case from Sweden. J. Destin. Mark. Manag. 2014, 3, 198-209. [CrossRef]

71. Marine-Roig, E.; Clavé, S.A. Tourism analytics with massive user-generated content: A case study of Barcelona. J. Destin. Mark. Manag. 2015, 4, 162-172. [CrossRef]

72. Raguseo, E.; Neirotti, P.; Paolucci, E. How small hotels can drive value their way in infomediation. The case of "Italian hotels vs. OTAs and TripAdvisor". Inform. Manag. 2016, 54, 745-756. [CrossRef]

73. Hu, Y.H.; Chen, Y.L.; Chou, H.L. Opinion mining from online hotel reviews-A text summarization approach. Inform. Process. Manag. 2017, 53, 436-449. [CrossRef]

74. Yin, R. Application of Case Study Research; Sage Publications Inc.: Newbury Park, CA, USA, 2003.

75. Stake, R.E. Multiple Case Study Analysis; Guilford Press: New York, NY, USA, 2013.

76. Yin, R. Case Study Research: Design and Methods; Sage Publication: Beverly Hills, CA, USA, 1994.

77. Kumar, N.; Anderson, J.C.; Stern, L.W. Conducting organizational research using organizational key informants. Acad. Manag. J. 1993, 36, 1633-1651.

78. Miles, M.B.; Huberman, A.M. Qualitative Data Analysis: A Sourcebook of New Methods; SAGE publications Inc.: Newbury Park, CA, USA, 1984.

79. Strauss, A.; Corbin, J.M.A. Grounded theory research: Procedures, canons, and evaluative criteria. Qual. Sociol. 1990, 13, 3-21.

80. Eisenhardt, K.M. Building theories from case study research. Acad. Manag. Rev. 1989, 14, 532-550. [CrossRef]

(C) 2018 by the authors. Licensee MDPI, Basel, Switzerland. This article is an open access article distributed under the terms and conditions of the Creative Commons Attribution (CC BY) license (http://creativecommons.org/licenses/by/4.0/). 